\title{
107. The Alleged Enzyme-Like Nature of the So-Called Causative Agent of Chicken Sarcoma.
}

\author{
By Waro Nakahara and Mizuho Sumi.
}

From the Institute of Physical and Chemical Research, and

The Government In stitute for Infectious Diseases, Tokyo Imperial University.

(Rec. June 1, 1927. Comm. by U. Suzuki, M.I.A., June 12, 1927.)

The view that chicken Sarcomas contain the so-called causative agent which is separable from sarcoma cells by filtration, desiccation, etc., has become almost traditional, but the nature of this hypothetical agent still remains undetermined. Rous ${ }^{1)}$ early suggested that the agent may be a ultramicroscopic virus, a theory which fails to explain the phenomenon of cellular specificity involved. Moreover, the recent experimental production by Carrel $^{2)}$ of " filterable" chicken sarcomas by means of coal tar, indole, or arsenious acid injections, renders the virus theory highly improbable. The view we have favored is that the so-called causative agent may be no other than certain sarcoma cells which withstand desiccation, and others which are filterable (Nakahara). ${ }^{3} \quad$ That the sarcoma produced by desiccated material or filtrate is due to the proliferation of these cells would seem obvious, but so far we have not been able to prove this point experimentally.

In the meantime, it was regarded as worth while to investigate other possibilities. The opinion seems to be current among recent workers that the so-called causative agent might be in the nature of enzyme-like substance (Ewing, ${ }^{4)}$ Murphy, ${ }^{5)}$ etc.). In this connection Professor U. Suzuki kindly called our attention to the method of acetonization, which kills yeast cells but preserves their full enzyme actions. Because of the crucial importance which this method might have in the study of the "agent question," we have tested out the

1) Rous, P. Jour. Amer. Med. Assoc., vol. 56, 198, 1911 ; Jour. Exper. Med. Vol. $13,397,1911$.

2) Carrel, A. Compt. rend. de la Soc. de Biol., T. 93, 491, 1083, 1278, 1925.

3) Nakahara, W. Science, vol. 64, 362, 1926 ; Centralb. f. allg. Path. u. path. Anat., Bd. 39, 103, 1927.

4) Ewing, J. Jour. Cancer Research, vol. 10, 269, 1926.

5) Murphy, J. B. Jour. Cancer Research, vol. 10, 274. 1926. 
effecs of acetonization on the transmissibility of the Rous chicken sarcoma. Incidentally, an observation was also made on the general enzyme actions of this tumor, using acetonized and non-acetonized materials. A brief summary of these investigations will be presented in this paper.

\section{Acetonized Chicken Sarcoma.}

The usual method of preparing the so-called "zymin" or " AcetonDauerhefe" was followed." A quantity of the fresh tissue of the Rous sarcoma No. 1 was strained through a fine wire mesh and was placed in about ten times its volume of acetone for fifteen minutes, stirring the mixture frequently so as to insure a uniform penetration of acetone. The sarcoma tissue was then recovered on filter paper, relieved of the excess acetone, allowed to dry in room temperature, and without washing in ether, was stored in a desiccation jar for a few days before using.

A bit of the acetonized sarcoma tissue was ground up in a mortar with a little salt solution, and smear preparations were made of the suspension for microscopical examination. It was found in all instances, that sarcoma cells were totally reduced to the state of necrosis, and in spite of repeated observations, not a single intact cell with normal structure was seen. Necrosis is proof of cell death since a cell undergoes it postmortem only.

As previously shown (Nakahara) ${ }^{2}$ the sarcoma tissue, when simply desiccated, always contains some morphologically intact and apparently viable sarcoma cells, as long as it retains the tumor producing action. The absence in acetonized material of apparently viable cells constitutes an important difference from the simply desiccated, non-acetonized material, which contains such cells. It may also be added that acetonization of previously simple desiccated material destroys these live-looking cells.

\section{Transmission Experiments.}

Experiment 1. -1 gram of acetonized sarcoma material prepared in the above described manner was ground up in $20 \mathrm{cc}$. of sterile distilled water and was injected intramuscularly in the right breast of 7 normal chickens in the amount of $2 \mathrm{cc}$. each $(0.1 \mathrm{gr}$. of acetonized material). At the same time the same amount of non-acetonized desiccate prepared from the same tumor was similarly suspended in distilled water and a

1) Jörgensen, A. Die Mikroorganismen der Garungsindustrie. Berlin. 1909.

2) Nakahara, W. Gann, Japan. Jour. Cancer Research, vol. 20, 13, 1926. 
corresponding amount of it was injected into the muscle of the left breast of the same chickens. In less than 3 weeks all the chickens developed typical sarcomas in the left breast at the site of the injection of non-acetonized material, but no sign whatever of tumor formation was noted in the right breast where acetonized material was injected. The chickens were kept under observation for two more weeks, but no tumor developed in the right breast.

Experiment 2.-6 normal chickens were injected in the right breast with suspension of acetonized material in $0.2 \mathrm{gr}$. amounts. No tumor developed during 4 weeks which followed. At the end of this period, chickens were given injections of the corresponding amounts of non-acetonized desiccate of the same tumor from which was prepared the acetonized material already injected. 3 weeks later, all the chickens showed fair sized tumors at the site of the second injection, but the right breast, where acetonized material was first injected, was entirely free from tumors.

Experiment 3.-10 normal chickens were injected in the right breast with suspension of acetonized material in $0.4 \mathrm{gr}$. doses. This lead to no tumor formation in any of the birds. 4 weeks later all the chickens were injected in the left breast with bits of fresh sarcoma tissue, which promptly produced large growths, killing all the chickens in 3 to 4 weeks time. The site of the injection of acetonized material never showed any sign of tumor.

These experiments prove conclusively that the tumor producing action of the sarcoma tissue is seriously impaired by, and probably does not survive, the process of acetonizatien.

\section{General Enzyme Actions.}

A survey of the general enzyme actions of the Rous chicken sarcoma may be of interest in connection with the above experiments.

Enzyme solution was preared by the usual method, extracting for 24 hours 4 grams each of simply dried material and of acetonized material separately in $200 \mathrm{cc}$. of sterile distilled water, in the presence of $5 \mathrm{cc}$. of chloroform. The water content of simply desiccated material was $6.54 \%$, that of acetonized sample $7.21 \%$. The pH of the enzyme solution of the former was 6.7 , that of the latter 6.8 .

The enzyme actions were tested by the established standard methods, using for controls (1) boiled enzyme solution, aud (2) distilled water in place of test solutions. The results are summarized in Table 1, where a comparison is made between the acetonized and non-acetonized materials. 
No. 6.] The Alleged Enzyme-Like Nature of the So-Called Causative.

Table 1. General enzyme actions of the Rous sarcoma.

\begin{tabular}{|c|c|c|c|c|c|}
\hline \multirow[b]{2}{*}{ Enzymes } & \multirow[b]{2}{*}{ Test substances } & \multirow[b]{2}{*}{$\mathrm{pH}$} & \multirow{2}{*}{$\begin{array}{l}\text { Period of } \\
\text { action }\end{array}$} & \multicolumn{2}{|c|}{ Enzyme actions } \\
\hline & & & & $\begin{array}{c}\text { Non-acetonized } \\
\text { material }\end{array}$ & $\begin{array}{c}\text { Acetonized } \\
\text { material }\end{array}$ \\
\hline Sucrase & Cane sugar & 5.6 & 24 hrs. & ++ & ++ \\
\hline Amylase & Soluble starch & 6.5 & 24, & $+t$ & ++ \\
\hline Emulsin & Salicin & 6.6 & $48 \quad ;$ & - & - \\
\hline Esterase & Ethyl butyrale & 8.0 & $30 \quad$, & + & + \\
\hline Lipase & Olive oil & - & $48 \quad$, & \pm & \pm \\
\hline \multirow[t]{2}{*}{ Pepsin } & Fibrin & - & 48, & \pm & \pm \\
\hline & Casein & - & 50 & \pm & \pm \\
\hline \multirow[t]{2}{*}{ Trypsin } & Fibrin & - & 68, & + & + \\
\hline & Casein & - & 50, & + & + \\
\hline Erepsin & Peptone & - & $48 \quad$, & + & + \\
\hline Nuclcase & Nucleic acid & 6.5 & 3 days & + & + \\
\hline Urease & Urea & 6.8 & $3 \quad$, & -- & - \\
\hline Lab & Milk & - & $5 \mathrm{hrs}$. & ++ & ++ \\
\hline \multirow[t]{2}{*}{ Oxidase } & Guaiacol & - & $5 \mathrm{~min}$ & - & - \\
\hline & Fyrogallol & - & $24 \mathrm{hrs}$. & - & - \\
\hline Peroxidase & Pyrogallol $+\mathrm{H}_{2} \mathrm{O}_{2}$ & - & $5 \mathrm{~min}$. & + & + \\
\hline Tyrosinase & Tyrosine & - & 50 hrs. & - & - \\
\hline Catalase & $\mathrm{H}_{2} \mathrm{O}_{2}$ & - & 3 & ++ & + \\
\hline
\end{tabular}

In the above table-indicates that the action was not clearly demonstrable, \pm weakly positive, + medium positive, and ++ strongly positive. The $\mathrm{pH}$ value is not given when buffer was not used.

As may be expected, no essential difference in the general enzyme action can be noted between the acetonized and non-acetonized materials. This is in striking contrast to the result of transmission experiments in which the acetonized material, unlike the non-acetonized, failed absolutely to produce sarcoma in susceptible chickens.

\section{Discussion and Summary.}

Whatever the true nature of the active agent in sarcoma transmission may be, surely we are not dealing with anything so simple as a 
growth stimulating substance. The process involved is even more complex than the malignant transformation of affected normal tissues. It is a case of the perpetuation of the specific type of cellular growth, regardless of the tissues with which the "agent" may be brought in contact. For instance, Rous' osteochondroma "agent" always reproduces the osteochondroma in the midst of any tissue into which it may be injected. ${ }^{1)}$ It does not localize in the preexisting cartilage and produce malignant transformation in it. True, a growth-stimulating enzyme may ultimately be discovered, but the postulate that a tumor enzyme may reproduce the same type of tumors without the presence of tumor cells cannot thereby be reasonably followed. Our experimental results show that the process of acetonization obviously kills the cells and destroys the transmissibility of the Rous sarcoma, although the general enzyme activities of the tissue suffer no essential loss. Hence it would seem unlikely that the " agent" responsible for the transmission of the Rous chicken sarcoma is in the nature of an enzyme.

1) Rous, P., etc. Jour. Amer. Med. Assoc., vol. 59, 1793, 1912. 